\title{
Surrey Wilfrid Laurence Jacobs 1946-2009
}

\author{
Karen L. Wilson
}

National Herbarium of New South Wales, Royal Botanic Gardens, Sydney, New South Wales 2000, Australia

Dr Surrey Jacobs was an outstanding Australian botanist, well-known in botanical circles around the world for his research on grasses, chenopods and waterplants. Locally, he was well respected also by those involved in understanding and managing plants in wetlands and grasslands.

Growing up in Sydney, Surrey dreamt of becoming a farmer, and he studied Agricultural Science at the University of Sydney as a step in that direction.

However, he developed more interest in plants themselves, and did an Honours project on the anatomy and systematics of the spinifex grasses (in the genera Plectrachne and Triodia) that dominate so much of the landscape in arid Australia. He followed this with a thesis on the ecology of these grasses for his PhD, awarded in 1974 by the University of Sydney. This interest in grasses led to a long career as a botanist at the National Herbarium of New South Wales in the Royal Botanic Gardens Sydney, starting in May 1971 and ending with his official retirement a fortnight before his untimely death from cancer on 26 November 2009.

Surrey could have had successful careers in agricultural science or ecology - his first publication was on the structure of plant communities (Anderson et al. 1967) - but he decided to channel his energies into plant systematics research. At the same time, he successfully integrated all his interests and training to broaden the scope of his studies.

His first big research project, for example, when he started work at the Royal Botanic Gardens Sydney was on the taxonomic significance of the variations in the photosynthetic carboxylation pathways. His collaborators in this included Assoc. Prof. Roger Carolin and Dr Maret Vesk from the University of Sydney, and Dr Elza Chapman (CSIRO Division of Food Research). This involved ultrastructural, anatomical and ecological studies concentrating on the families Poaceae (Carolin et al. 1973), Chenopodiaceae (Carolin et al. 1975, 1982), Cyperaceae (Carolin et al. 1977), Aizoaceae, Portulacaceae, Amaranthaceae and other families of the order Caryophyllales (Carolin et al. 1978). Field measurements of the different physiological responses to variations in the local environmental conditions were made for species with the different pathways (Chapman \& Jacobs 1980, Raison et al. 1979). The successful use of laboratory-oriented techniques and equipment in the field proved a breakthrough in itself, and the results obtained indicated that previous results from studies in controlled environments bore scant resemblance to actual field behaviour, at least for many native Australian species. These approaches were notable in that they were at the intersection of physiology, anatomy, ecology and taxonomy and solved several problems in classifications, helped generate 
hypotheses on evolution in some genera and the relationships between genera, and allowed more reliable predictions of physiological characteristics (and hence growth) of many species.

During the 1970s, he and a colleague, ecologist John Pickard, coordinated the assembly of the first list (census) of plant species growing in New South Wales (Jacobs \& Pickard 1981) since Maiden and Betche compiled their census (Maiden \& Betche 1916).

Surrey's subsequent studies concentrated more on taxonomic projects. The death of Dr Joyce Vickery in May 1979 led to him completing projects she had initiated, notably the major revision of the species of Stipa (about 66 spp.) in Australia (Vickery et al. 1986). Studies on Stipa and related genera continued with colleague Joy Everett and Dr Mary Barkworth of Utah State University, USA. Their work (Jacobs and Everett 1996) resulted in the Australian native species being transferred to a new genus Austrostipa (93 spp.) and the reassessment of non-Australian species, including several seriously weedy species now placed in the genus Nassella. They formed the Stipoid Working Group with research workers from Australia, USA, Argentina, Spain, Romania, Germany and Czechoslovakia, to move towards a consistent classification of the whole tribe using both molecular and more traditional methods.

Surrey also developed research programs into the classification, naming and phylogeny of Chenopodiaceae, waterplants and weeds.

$\mathrm{He}$ was one of the Botanic Gardens' most productive botanists, resulting in his promotion to Senior Principal Research Scientist in 2008 - the most senior research scientist rank in the New South Wales Public Service. He authored over 120 scientific publications (see the list of publications in this issue), often in collaboration with colleagues here and overseas, and these form a major contribution to our knowledge of the world's plant diversity. He named over 80 Australian plant genera and species.

His greatest impact was probably in waterplants (Fig. 1), many of which were relatively poorly understood in Australia before he started his research, despite their economic importance. In recognition of this, he received the T. Wayne Miller Distinguished Service Award from the international Aquatic Plant Management Society in 2009 only the third recipient of that award - and was posthumously made a member of the Hall of Fame of the International WaterLily and Water Garden Society in 2010.

Vallisneria provides an example of the importance of his waterplant research. Species of Vallisneria are both a major source of income for growers of aquarium plants and a major weed of irrigation systems. Problems with inconsistency of control methods were overcome when he established that there are five species (not two, as previously thought) in Australia, and that there are two species (not one) causing problems in irrigation systems. The species have always been difficult to identify morphologically, and the molecular analyses carried out jointly with Dr Don Les from the University of Connecticut, USA, have shed light on relationships, evolution and status of the described species (Les et al. 2008). They found that the common southern Australian species is not the same as the North American V. americana - not even a close relative despite being difficult to separate on morphological characters alone. They also showed that the very common and widespread species of Vallisneria used in aquaria around the world is the Australian V. nana, not V. spiralis, the name it used to be sold under.

Another particularly notable contribution by Surrey was to the systematics of the water-lilies, the genus Nymphaea (Fig. 2). This group is now much better known, 


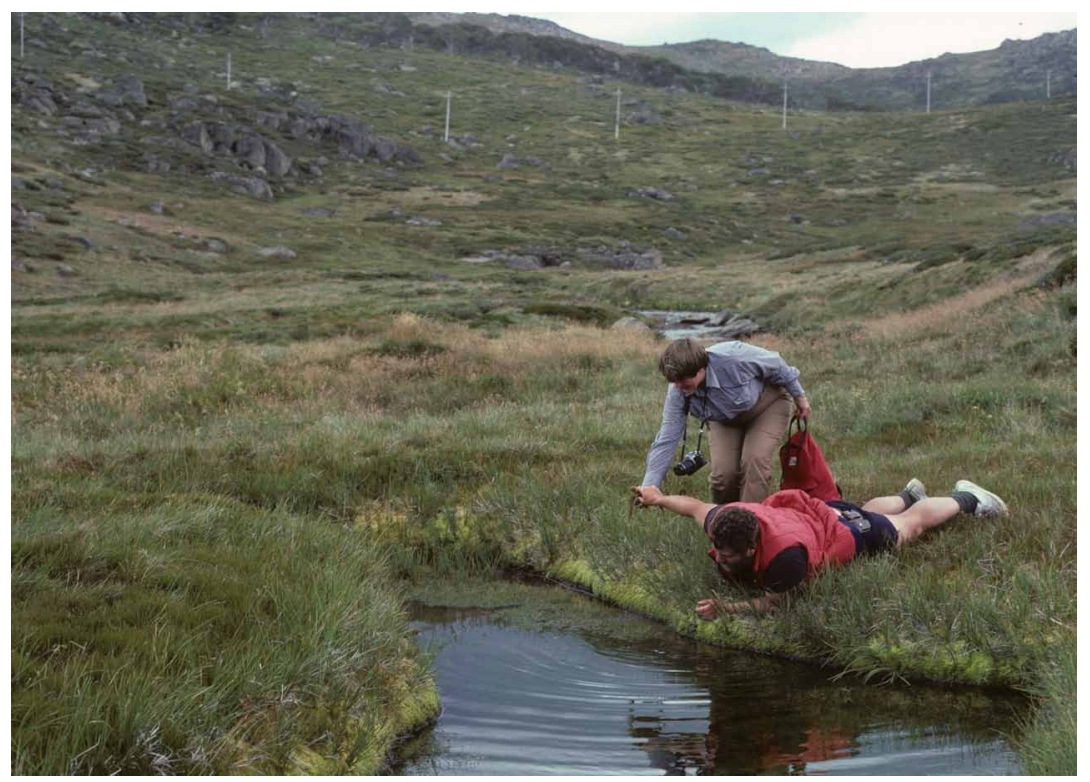

Fig 1. Surrey Jacobs collecting in Betts Creek with Karen Wilson assisting, Snowy Mountains, NSW, 1985 (Photo: Barbara G. Briggs)

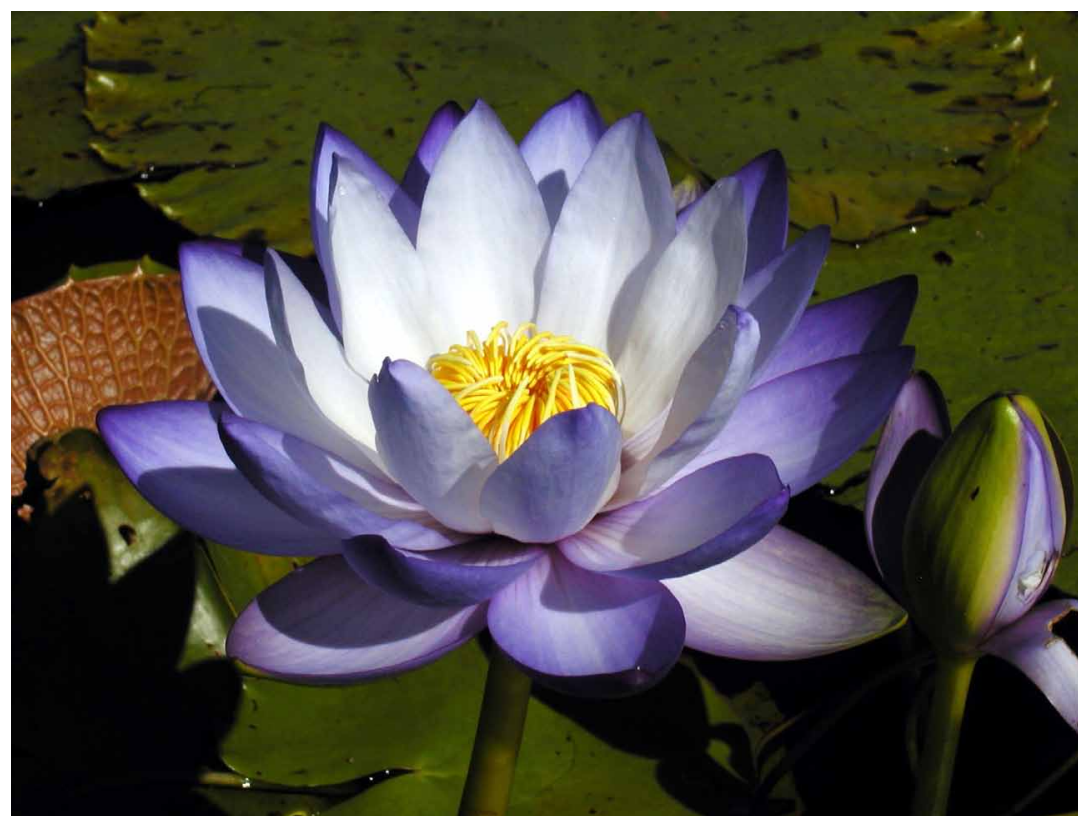

Fig. 2. Nymphaea jacobsii Hellq., a new species collected from Lake Powlathanga, Qld, by Surrey Jacobs and Barre Hellquist and described in this issue of Telopea (p. 238). (Photo: C. Barre Hellquist) 
thanks to extensive field observations in northern Australia and southern Papua New Guinea and the morphological and molecular studies - involving Dr Barre Hellquist of the Massachusetts College of Liberal Arts, USA, and other collaborators - that have revealed the complexities of the genomes and relationships in this decorative genus (Jacobs 1992, Jacobs \& Hellquist 2006, Jacobs \& Porter 2007, Löhne et al. 2008).

One of his waterplant collaborators, Don Les, expands in this issue on this area of Surrey's research. Don highlights well the affectionate esteem in which Surrey is held by so many collaborators and colleagues - also demonstrated by the range of contributors to this special issue in his honour.

Surrey filled the post of Australian Botanical Liaison Officer at the Royal Botanic Gardens Kew from August 1983 to August 1984. As for many other Australian botanists, this was an opportunity not just to use Kew's great botanical resources relevant to Australian botany but also to visit European herbaria and to meet botanists from many other parts of the world, Kew being a veritable botanical Piccadilly Circus. He forged collaborations and friendships at that time that led to numerous international collaborative projects.

Conscious of the need to make research results available to the wider community, Surrey often advised, for example, on wetland plant management and provided forensic advice on plants connected with police investigations. He was author or coauthor of over 60 extension-oriented publications, including a range of semi-popular books such as Waterplants of New South Wales (Sainty \& Jacobs 1982), Waterplants in Australia (now in its fourth edition; Sainty \& Jacobs 2003), Grasses of New South Wales (now in its fourth edition; Jacobs et al. 2009), Australian Agricultural Botany (Jackson \& Jacobs 1985) and Burnum Burnum's Wild Things (in its second edition; Sainty et al. 2000). Many of these were written with Geoff Sainty, another local waterplant and weed expert and another excellent photographer of plants. These two good friends and colleagues thought nothing of standing in water or lying on a wet bank, ignoring leeches and other biting creatures in pursuit of a good close-up of a flower. In the last few years, however, both drew the line at wading in tropical regions: the crocodiles are getting too big and too numerous.

In the last two decades, Surrey's knowledge of waterplants led to him being appointed to several State Government scientific advisory committees involved in implementing the State's wetland management policy and monitoring environmental conditions and flows in New South Wales rivers (Fig. 3). He worked with experts from other disciplines and departments to produce a manual and protocols for rapid assessment of stream condition using macrophytes and other indicators (Jacobs et al. 1997, Jacobs 1998).

One of his many collaborations with Geoff Sainty (who is an Honorary Research Associate of the National Herbarium of New South Wales) was to develop a way to assess wetlands in the Hawkesbury River catchment. The method they developed is now widely used, often inappropriately as Surrey once wryly commented. He supervised a postgraduate student, Joanne Ling, who examined the effects of sampling errors in rapid and other assessment techniques and redesigned these techniques to produce a more generally applicable wetland assessment method (Ling \& Jacobs 2003). Another student, Joanne Green, worked on similar problems in assessing saltmarshes and their rehabilitation (Green et al. 2009).His interest in waterplants and weeds intersected 
his involvement with the (then) New South Wales Department of Agriculture and the National Co-ordinating Committee on Aquatic Weeds, advising on national and State weed issues, particularly aquatic weeds. He was also asked by the Australian Weeds Committee, in conjunction with the Australian Quarantine Inspection Service, to help formulate a procedure for assessing the weed-potential of species proposed for importation into Australia.

He was a key member of the committee that organised the joint Second International Conference on Monocotyledons and Third International Grass Conference in Sydney in September 1998. One volume of the proceedings from these meetings was edited by Surrey and Joy Everett (Jacobs \& Everett 2000).

In the educational area, Surrey was involved in the NSW Department of Education's Murder under the Microscope - an annual competitive, on-line game aiming to excite children's interest in science and the environment. The first few Education Officers at the Botanic Gardens appreciated his support and encouragement as they set up and developed the educational services provided there. He was an Adjunct Associate Professor at the University of New England from 2000, working as a member of a group including botanists from the Botanic Gardens, zoologists from the Australian Museum, and university staff to develop and teach an advanced undergraduate course in Biosystematics. He supervised or informally advised a range of postgraduate students on systematic, ecological and conservation- or agricultural-oriented projects.

The state of Surrey's office and his usually rather casual dress misled some people initially, but they soon learned that he was extremely organised in his work, and both practical and knowledgeable. He had an enquiring mind and a good memory, and he was thorough - all good traits for anyone, but particularly important for a systematics botanist. As a friend remarked recently, Surrey was a 'walking encyclopaedia' in the old hard-copy terminology. He embraced new techniques as they appeared, such as electron microscopy and molecular analysis, to augment traditional approaches to understanding the systematics of grasses, chenopods and waterplants.

Surrey's methodical and persistent approach was demonstrated admirably in the last year of his life. He went on sick leave after being diagnosed in late 2008 but managed to continue his research until the last few months of his life. In this period, he completed and submitted several manuscripts on grasses, waterplants and chenopods in collaboration with colleagues in Australia and overseas. Moreover, he arranged the sending of materials to his collaborators for them to finish uncompleted projects.

Like everyone, Surrey was a complex mixture of positive and negative traits. He had a commonsense approach to innumerable matters, and was both generous and patient in imparting his knowledge to others, in fields as varied as photography, laboratory work, statistical analysis, and fieldwork. He was a mentor and advisor to many younger staff and students, and was an excellent listener for those with personal issues. As his daughter Ellen said in her oration at his funeral, he taught his children to 'gather all the facts and always take time to listen to people', but also to 'stick to your guns and not be afraid to say it how it is'. The latter at times left Surrey in conflict with others. He had little patience with those he regarded as 'fools or knaves' (I use the $2^{\text {nd }}$ Duke of Buckingham's words, not Surrey's). And what was steadfastness in some situations became stubbornness in others, as family, friends and colleagues well knew. However, the positive traits far outweighed the negative. 
Fieldwork was a major part of his life and work: he would not have achieved his deep understanding of plants without the extensive trips he undertook in all parts of Australia (Fig. 4). He was never happier than when he was standing waist-deep in water collecting an interesting water-lily or standing in red dust collecting and photographing a grass. His many field trips in northern Australia included taking part in the 1988 Royal Geographical Society scientific expedition to the Kimberley region of WA that marked the bicentenary of Australia's settlement by Europeans. And in February 1992 he went on the Royal Geographical Society of Queensland's scientific expedition to the northern part of Cape York Peninsula. He was a very thorough, careful worker in the field - and he had a reputation amongst his colleagues as an excellent camp-cook. He was also renowned for his snoring; those in the know pitched their tents at the opposite end of the campsite.

Surrey Wilfrid Laurence Jacobs was born in Sydney on 29 April 1946, the second child and only son of Wilfrid Jacobs, an industrial chemist at the Federal Match Company in Sydney (ultimately Works Manager there), and Viola née Sundstrom. His grandfather Ernest Godfried Jacobs taught botany at Sydney Technical College early last century and provided a botanical model for Surrey and his older sister Janice (now retired), who had a long botanical career in the School of Biological Sciences at the University of Sydney. Their younger sister Wendy Innes has also kept a link with plants, running a family nursery and blueberry-growing business.

Surrey met his future wife Betty Luscombe while tutoring at the University of Sydney during his doctoral studies. Betty graduated as a science teacher, and they married in 1971. She became the first Education Officer at the Royal Botanic Gardens Sydney in 1972, and left in 1976 to have their two children, Ellen and Geoffrey.

Even when young, their children learnt the scientific names of plants and had no fear of using them. When just two years old, Ellen entered an adult-education plant identification class with her father, pointed to the grass-tree specimen on display, and said "Look, Daddy, a Xanthorrhoea", thereby silencing members of the class who had been complaining to the teacher (Betty) about the difficulties of using scientific names.

Surrey was very lucky in his choice of life partner: he couldn't have achieved nearly so much without the support of Betty. In particular, they were very welcoming hosts to many botanical visitors from around the world.

Botany may have been Surrey's passion, but he was also a very loving family man, despite what his family may have thought sometimes, given his many field trips and long days at work. He named species of grasses and waterplants after Betty, Ellen, Geoff, and Ellen's sons Alex and Luke Fussell.

Surrey relaxed by collecting model trains and cars and making excellent jams of many kinds, mostly given away to appreciative friends and colleagues. He was the jam-maker in the family but the jams were labelled as Mrs Jacobs' Jams and Jellies - as Surrey noted, Dr Jacobs' Jams and Jellies didn't have quite the right ring. He sublimated his agricultural interests by breeding chickens at the back of their suburban quarter-acre block: Silkies, Sussex (also known as Surreys) and others. Family and friends were regularly supplied with fresh eggs of various sizes.

Surrey was a larger than life character in many ways, but he was also a self-deprecating man. He once said that he had been in awe of his predecessor Dr Joyce Vickery for her extensive research on grasses. His successors will be equally in awe of Surrey. He has a 


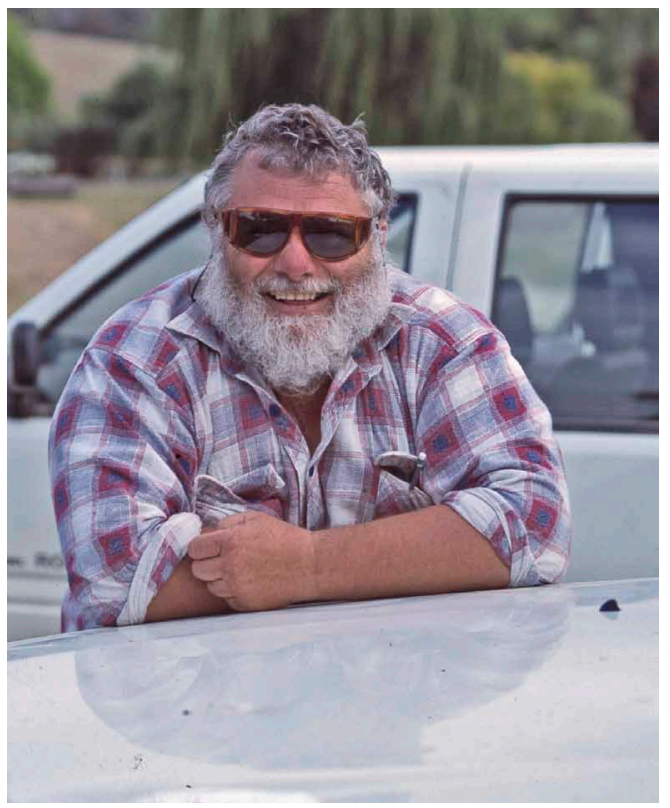

Fig. 3. Surrey taking a break from monitoring water plants along the Snowy River, at Willis, Vic, 1999. (Photo: Geoff Sainty)

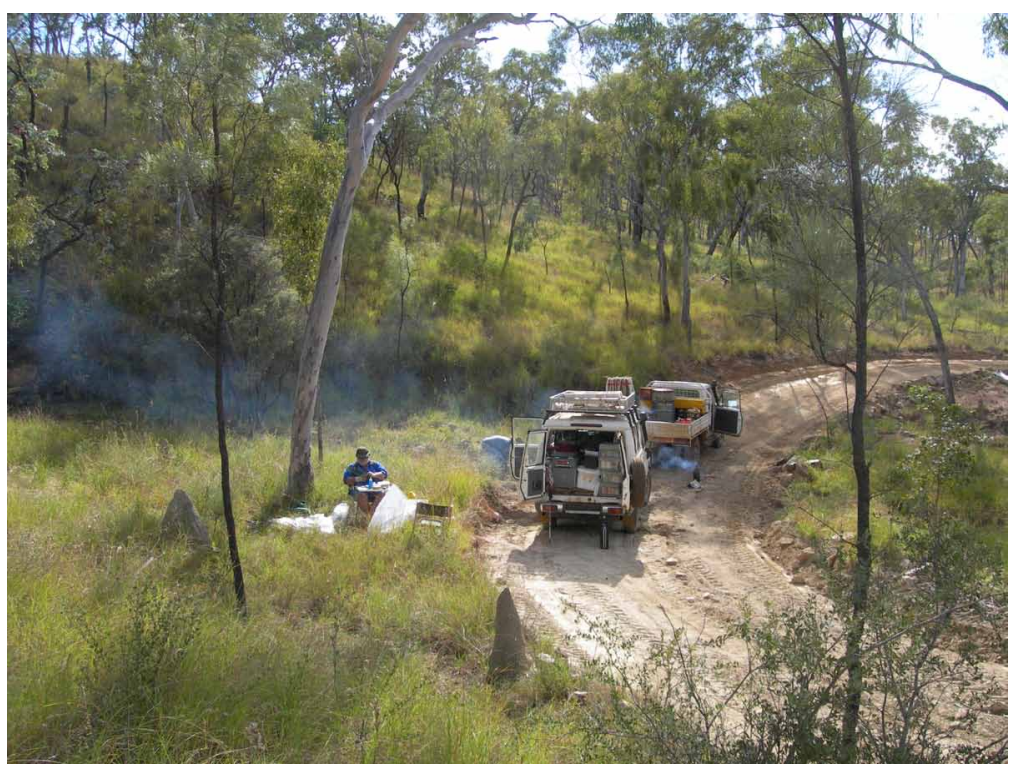

Fig. 4. Surrey processing specimens while the billy boils, central Qld, 2006. (Photo: Jane Dalby) 
permanent memorial in his botanical publications and in the plant species named by him and after him. In the more public sphere, he was awarded a Public Service Medal in 2009 for his contribution to systematic botany in Australia.

\section{References}

Anderson, DJ, Jacobs SWL \& Malik AR (1967) Studies on structure in plant communities VI. The significance of pattern evaluation in some Australian dry-land vegetation types. Australian Journal of Botany 15: 315-322.

Carolin RC, Jacobs SWL \& Vesk M (1973) The structure of the cells of the mesophyll and parenchymatous bundle sheath of the Gramineae. Botanical Journal of the Linnean Society 66: 269-273.

Carolin RC, Jacobs SWL \& Vesk M (1975) Leaf structure in the Chenopodiaceae. Botanische Jahrbücher für Systematik 95: 226-255.

Carolin RC, Jacobs SWL \& Vesk M (1977) The ultrastructure of Kranz Cells in the family Cyperaceae. Botanical Gazette 138: 413-419.

Carolin RC, Jacobs SWL \& Vesk M (1978) Kranz cells and mesophyll in the Chenopodiales. 1978. Australian Journal of Botany 26: 683-698.

Carolin RC, Jacobs SWL \& Vesk, M (1982) The chlorenchyma of some members of the Salicornieae. Australian Journal of Botany 30: 387-392.

Chapman EA \& Jacobs SWL (1980) Photosynthetic responses of some arid zone plants. Studies in the Arid Zone 4: 41-53.

Green J, Reichelt-Brushett A \& Jacobs SWL (2009a) Re-establishing a saltmarsh vegetation structure in a changing climate. Ecological Management \& Restoration 10: 20-30.

Jackson DL \& Jacobs SWL (1985) Australian Agricultural Botany. 377pp. (Sydney University Press: Sydney)

Jacobs SWL (1992) New species, lectotypes and synonyms of Australasian Nymphaea (Nymphaeaceae). Telopea 4: 635-641.

Jacobs SWL (1998) Monitoring and assessing wetlands using macrophytes. Pp. 34-37 in Brady A (ed.) Proceedings of the Department of Land and Water Conservation Wetlands Conference and Workshop, 28-30 April, 1997, Myall Lakes. (Department of Land and Water Conservation: Parramatta)

Jacobs SWL \& Everett J (1996) Austrostipa, a new genus, and new names for Australasian species formerly included in Stipa. Telopea 6: 579-595.

Jacobs SWL \& Everett J (eds) (2000) Grasses, systematics and evolution. 406 pp. (CSIRO Publishing: Melbourne)

Jacobs SWL \& Hellquist CB (2006) Three new species of Nymphaea (Nymphaeaceae) in Australia. Telopea 11: 155-160.

Jacobs SWL \& Pickard J (1981) Plants in New South Wales. 227 pp. (New South Wales Government Printer: Sydney)

Jacobs SWL \& Porter CI (2007) Nymphaeaceae. Pp 259-275 in Wilson AJG (ed.), Flora of Australia vol 2. (ABRS: Canberra; CSIRO Publishing: Melbourne)

Jacobs SWL, Lindsay G, Sainty G \& Skelton N (1997) Wetland and saltmarsh assessment: vegetation based protocols and database. pp 152-155 in Riley S, Erskine W \& Shrestha S, Proceedings of the Conference on Science and Technology in the Environmental Management of the Hawkesbury-Nepean Catchment. Institution of Engineers Australia National Conference Publication NCP 97/01; Geographical Society of New South Wales Conference Papers No. 14.

Jacobs SWL, Whalley RDB \& Wheeler DJB (2009) Grasses of New South Wales, $4^{\text {th }}$ edition. (School of Environmental and Rural Science, University of New England: Armidale)

Les DH, Jacobs SWL, Tippery N, Lei Chen, Moody ML \& Wilstermann M (2008) Systematics of Vallisneria L. (Hydrocharitaceae Juss.) Systematic Botany 33: 49-65. 
Ling JE \& Jacobs SWL (2003) Biological assessment of wetlands: testing techniques - preliminary results. Wetlands 21 (1) 36-55.

Löhne C, Borsch T, Jacobs SWL, Hellquist CB \& Wiersma J (2008) Nuclear and plastid DNA sequences reveal complex evolutionary patterns in Australian water-lilies (Nymphaea subgenus Anecphya, Nymphaeaceae). Australian Systematic Botany 21: 229-250.

Maiden JH \& Betche E (1916) A census of the flowering plants of New South Wales. (Government Printer: Sydney)

Raison JK, Chapman EA, Wright LC \& Jacobs SWL (1979) Membrane lipid transitions: their correlation with the climatic distribution of plants. Pp. 177-186 in Lyons JM, Graham D \& Raison JK (eds), Low temperature stress in crop plants: the role of the membrane. (Academic Press: New York)

Sainty GR \& Jacobs SWL (1982) Waterplants of New South Wales. 550 pp. (Water Resources Commission, New South Wales: Sydney)

Sainty GR \& Jacobs SWL (2003) Waterplants in Australia, $4^{\text {th }}$ edition. 416 pp. (Sainty and Associates: Sydney)

Sainty G, Hosking J, Abell P, Jacobs S \& Dalby-Ball M (2000) Burnum Burnum's Wildthings. (Sainty and Associates: Potts Point)

Vickery JW, Jacobs SWL \& Everett J (1986) Taxonomic studies in Stipa (Poaceae) in Australia. Telopea 3: 1-132.

Manuscript received 26 October 2010, accepted 19 November 2010 